
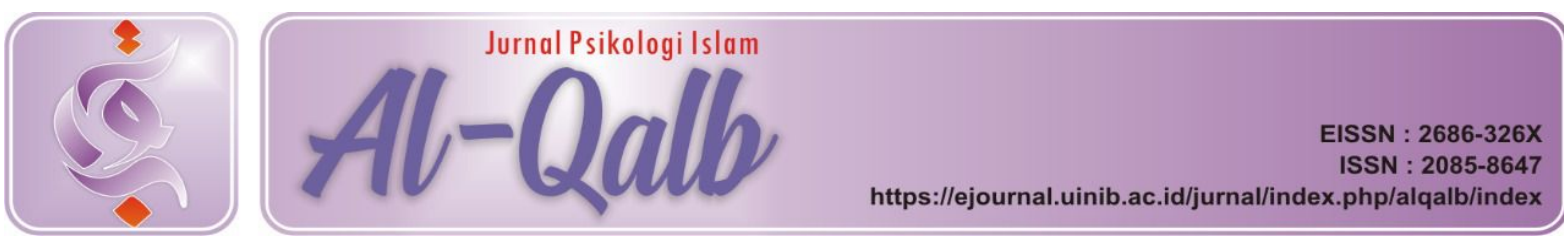

\title{
SYAMDUDDIN SUMATRANI: TOKOH TASAWUF DARI ACEH
}

\author{
Received: 27th December 2014; Revised: 09th January 2015; Accepted: $19^{\text {th }}$ February 2015
}

\section{Sy. Dt. Parpatih}

IAIN Imam Bonjol Padang

Email: datuk_parpatih@ymail.com

\begin{abstract}
Abstrak: Artikel ini memaparkan tokoh Syamsuddin Sumatrani merupakan ulama tokoh tasawuf terkemuka yang menyebabkan tasawuf wujudiyyah yang mengandung faham wahdatul wujud yang kemudian diduduki oleh Nuruddin sebagai ajaran sesat, kafir dan zindiq, sehingga sebagian besar karya-karya ulama tersebut dimusnah-kan dan dibakar. Sedikit sekali informasi ditemukan oleh para peneliti tentang diri Syamsuddin Sumatrani, sehingga potret pribadinya yang dapat diberikan masih amat jauh dari lengkap.
\end{abstract}

Kata Kunci : Syamsuddin Sumatrani, Tasawuf Wujudiyyah, Aceh

$\mathrm{J}$ ulukan Aceh sebagai serambi Mekah tidak terlepas dari eksis-tensi proses Islamisasi di Aceh. Proses Islamisasi di daerah ini merupa-kan proses Islamisasi yang paling awal bila dibandingkan dengan wilayah lain di Nusantara. Menurut sebagian para ahli sejarah, pada tanggal 1 Muharram $225 \mathrm{H}$ kera-jaan Peureulak diproklamirkan menjadi sebuah kerajaan Islam dengan rajanya Sultan Alaidin Saiyid Maulana Abdul Aziz Syah. Kemudian berdiri pula kerajaan Is-lam Samudera Passai dengan rajanya Al Malik Al Saleh (650-688 H/ 1261 - $1289 \mathrm{M}$ ) dan kemudian diikuti pula dengan lahirnya kerajaankerajaan Islam lainnya.

Pada tanggal 12 Dzulqaidah $916 \mathrm{H}$ diproklamirkan berdirinya kera-jaan Aceh Dar Al-Salam dengan Sultan Alaidin Ali Munghayat Syah sebagai rajanya. Kerajaan Islam ini merupakan gabungan dari peleburan kerajaan Islam Peureulak, kerajaan Islam Samudera Passai, kerajaan Is-lam Benua, kerajaan Islam Pidie, sampai ke Puncu di pantai Utara dan Barus di Pantai Barat serta Pa-garuyung, Rengat,
Jambi sampai ke Selat Malaka.Dalam perjalanan sejarahnya, Ke-rajaan Islam Aceh Dar Al Salam mengalami pasang naik dan pasang surut, bahkan sampai runtuh. Zaman keemasan Kerajaan Islam Aceh Dar Al Salam terjadi pada akhir abad ke-16 sampai akhir abad ke-17 yaitu sejak pemerintahan Sultan Alauddin Riayat Syah Al Mukamil (1589 - 1604 M) sampai kepada masa Ratu Taj Al Alam Safiatuddin. Pada masa itulah muncul ulama-ulama besar yang memiliki kelas internasional dari negeri Aceh itu yang ahli dalam berbagai cabang ilmu pengetahuan terutama ilmu pengetahuan Islam dalam berbagai bidang. Ulama-ulama tersebut adalah seperti Hamzah Fansuri, Syamsuddin Sumatrani atau Syamsuddin Passai Nuruddin Al Raniri dan Abdul Rauf Singkel.

Syamsuddin Sumatrani dan gurunya Hamzah Fansuri merupakan dua ulama tokoh sufi terkemuka yang menyebabkan tasawuf wujudiyyah yang mengandung faham wahdatul wujud yang kemudian diduduki oleh Nuruddin sebagai 
ajaran sesat, kafir dan zindiq, sehingga sebagian besar karya-karya kedua ulama tersebut dimusnahkan dan dibakar. Ketika Nuruddin Al Raniri menjadi Syaikhul Islam yang mengakibatkan sedikit sekali dijumpai karya kedua ulama tersebut saat ini. Pengajaran Syamsuddin Sumatrani tentang Tuhan dengan co-rak paham wahdat al wujud, dikenal juga dengan pengajaran tentang "Mar-tabat Tujuh" yakni tentang satu wujud dengan tujuh martabatnya. Pada makalah ini penulis akan mengemukakan riwayat hidup Syamsuddin Sumatrani dan secara umum pengajarannya tentang wahda-tul wujud, serta pengajarannya ten-tang Martabat Tujuh.

\section{PEMBAHASAN}

\section{Riwayat Hidup dan Karyanya}

Riwayat hidupnya Syamsuddin Sumatrani nama lengkapnya adalah Syekh Syamsuddin bin Abdillah Su-matrani, sering juga disebut Syamsud-din Passai. Sering disebut Syamsuddin Sumatrani karena ia ada-lah orang Sumatera. Selain itu juga sering disebut Syamsuddin Passai, hal ini tentu saja dikaitkan dengan negerinya Passai di Sumatera Utara. Daerah istimewa Aceh, yang setelah era Reformasi menjadi provinsi Nanggroe Aceh Darus-salam, tepatnya dalam wilayah kabu-paten Aceh Utara. Negeri Passai terletak beberapa kilometer arah barat Lhok Seumawe, ibukota Aceh Utara yang disana terdapat makam Al Malikas Saleh, salah seorang raja Kerajaan Islam Samudera Passai. Ada beberapa kemungkinan tim penu-lis mengatakan bahwa Passai di Sumatera Utara. Pertama mungkin yang dimaksudkan adalah Passai be-rada di Sumatera bagian Utara, atau Passai ketika secara keseluruhan ber-sama wilayah Aceh lainnya berada dibawah satu provinsi yaitu provinsi Sumatera Utara. Atau mungkin juga karena Sumatera Utara dulunya terma-suk kedalam wilayah Kerajaan Islam Samudera Passai. Beliau ada-lah seorang keturunan ulama, ayahnya bernama Abdullah as Sumatrani, ia mendapat pendidikan keshufian dari Syeh Hamzah Fansuri dan kemudian pernah belajar kepada Sunan Bonang di Jawa. (Hawas Abdullah, 1980, 40). Sedangkan nama ibunya tidak disebutkan begitu juga tempat, tanggal, bulan, dan ta-hun lahirnya tidak ditemui informasi yang pasti.

Sedikit sekali informasi ditemukan oleh para peneliti tentang diri Syamsuddin Sumatrani, sehingga potret pribadinya yang dapat diberi-kan masih amat jauh dari lengkap. Informasi dari sumber-sumber Timur hanyalah dari Hikayat Aceh, Adat Aceh dan Bustan al Salathin. Se-dangkan dari sumber-sumber Barat adalah dari kisah kisah perjalanan Frederich de Houtman, James Lancester dan John Davis ke Aceh. (Abdul Aziz, 1999, 13). Namun demikian, dalam beberapa catatan para ahli sejarah menyebutkan bahwa ia hidup antara tahun 1575 sampai tahun 1630, sedangkan dari bahan informasi yang terbatas itu para peneliti dapat memahami bahwa Syamsuddin Sumatrani adalah Syaikh al Islam (gelar tertinggi untuk ulama, qadi, imam atau syekh) pena-sehat raja, imam kepala, anggota tim perunding dan juru bicara kerajaan Aceh Darussalam, dan cukup lama berperan sebagai orang penting itu dalam lingkungan Istana, lebih dari tiga dasawarsa dan boleh jadi penuh, atau lebih dari empat dasawarsa. Ia sudah tampak berperanan di Istana pada awal dasawarsa terakhir abad ke 16 dan wafat akhir dasawarsa ke-tiga abad ke 17, dan tidak ada petun-juk bahwa ia pernah disingkirkan dari peranannya dilingkungan Istana Aceh Darussalam. Hal ini mengandung isyarat bahwa ia ulama yang memiliki keunggulan lebih dari ulama ulama yang lain pada masanya. Ia masyhur dalam ilmu ta-sawuf, alim dalam segala ilmu se-perti kata Nasrudin al Raniri serta fasih berbicara dalam bahasa arab sehingga 
ia ditugaskan juga sebagai juru runding dengan perutusan negara luar. (Abdul Aziz, 1999, 19).

Syamsuddin Sumatrani dalam informasi yang ada muncul dengan tiba-tiba sebagai seorang ulama, orang penting, bahkan seorang Sufi, karena tidak adanya informasi ten-tang latar belakang di mana ia lahir, kehidupan masa kanak-kanak, masa remaja, dimana saja ia belajar, negeri-negeri mana saja yang ia jela-jahi dalam menuntut ilmu, tingkat sekolah apa saja yang dijalaninya. Hal ini tidak diketahui sama sekali dan tidak tersingkapkan dengan jelas. Kendati demikian, latar belakang ke-hidupan keagamaan di Aceh banyak atau sedikitnya tentu berperan bagi kemunculannya sebagai ulama atau sufi yang masyhur dan disegani. Ka-rena negeri Passai yang kepadanya dinisbatkan pribadi Syamsuddin lebih dahulu terkemuka dari pada Banda Aceh dalam hal sebagai pusat pengajaran dan pengembangan Islam pada abad ke-14 dan $15 \mathrm{M}$. Hal itu memungkinkan, karena banyaknya kehadiran ulama dari negerinegeri belahan Barat laut seperti India, Persia dan Jazirah Arab di Samudra Passai, karena Passai terletak pada jalur pelayaran dari Barat ke Timur seperti Asia Tenggara dan Cina untuk perdagangan.

$$
\text { Mengenai hubungan antara }
$$
Syamsuddin Sumatrani dengan Ham-zah Fansuri, bahwa Syamsuddin Sumatrani salah seorang diantara murid dan pendukung kuat dari Ham-zah Fansuri. Pendiriannya meru-pakan cermin dari Hamzah Fansuri, karena telah dijumpai 2 karya tulis Syamsuddin Sumatrani yang merupa-kan ulasan (syarh) terhadap pengajaran Hamzah Fansuri. Kedua karya Syamsuddin Sumatrani itu ada-lah Syarah Rubai Hamzah Fansuri dan Syarah Syair Ikan Tongkol hanya saja tidak ada informasi dimana ia belajar dengan Ham-zah Fansuri, apalagi dengan ulama-ulama lain.
Bagaimanapun terbatasnya informasi tua, kesan-kesan kuat yang ditimbulkan oleh kajian-kajian para sarjana selama ini adalah bahwa Syamsuddin Sumatrani adalah satu dari empat ulama yang paling terkemuka, ber-pengaruh besar, atau berperan besar dalam sejarah pembentukan atau pengembangan intelektual keislaman di Aceh pada abad ke-17 dan bebe-rapa dasawarsa sebelumnya. Keem-pat ulama tersebut adalah Hamzah Fansuri (?-?), Syamsuddin Sumatrani (?-1630), Nuruddin al Raniri (?-1658) dan Abdul Rauf Singkel (1615/20-1693). Mengenai wafatnya Syamsuddin Sumatrani dijumpai dari karya tulis Nuruddin al Raniri, Bustan al Salathin bahwa Syamsuddin Sumatrani wafat pada tahun $1630 \mathrm{M} / 1039 \mathrm{H}$, sedangkan tahun kelahirannya tidak diketahui, (Tim Penulis IAIN SH, 1992, 891), begitu juga tidak didapat keterangan kelahirannya pada buku-buku lain. Sedangkan dalam lapangan Fiqih ia bermazhab Syafi'i dan ini tidak aneh. Tidak ada halangan bagi penganut tasawuf wahdat al wujud, atau tasawuf bukan wahdat al wujud untuk bermahzab syafi'i atau mazhab lainnya dalam lapangan fiqih (Abdul Aziz, 1999, 25), karena memang tidak ada larangan tentang hal terse-but, dan kedua-duanya menuju kepada suatu tujuan, yang satu melalui syariah dan lainnya menempuh jalan Thariqah dan Haqiqah.

\section{Ajaran Syamsuddin Sumatrani tentang Tuhan, Alam dan Manusia}

Shaikh Syamsuddin Sumatrani yang merupakan murid dan sahabat terpenting dari Hamzah Fansuri, hidup diperkirakan sekitar tahun 1575 hingga tahun $1630 \mathrm{M}$. Kedua ulama ini memegang peranan penting dalam membentuk pemikiran keagamaan kaum muslimin Melayu Nusantara pada paruh pertama abad ke 17, khususnya atas paham wahdatul wujud. 
Berbeda dengan gurunya, Syamsuddin Sumatrani bukan saja mengembangkan dan me-nyebarluaskannya di lingkungan istana dan masyarakat luas, Syaikh juga memberikan warna baru ter-hadap wujudiah yang dikenal dengan faham Martabat tujuh( Duski Samad, 2000, 19) dan banyak orang mengira bahwa ajaran wujudiah yang berkem-bang di Indonesia sampai saat ini hampir semuanya adalah ajaran Martabat tujuh. Pendapat demikian tidak benar, sebab ajaran Martabat tujuh baru berkembang pada awal abad ke 17 dengan Syaikh Syamsud-din Passai sebagai pengajarnya yang pertama. Memang Martabat tujuh termasuk ajaran wujudiah namun telah menempuh perkembangan agak lain dan ke dalamnya telah masuk pengaruh India, seperti praktek yoga di dalam amalan dzikir nya, sesuatu yang dikritik oleh Syaikh Hamzah Fansuri. Maklum pengasas pertama ajaran Martabat tujuh adalah Muham-mad Fadhullah al Burhanpuri (w-1620) yang berasal dari India (Ab-dul Hadi, 2000, 19) dan doktrin utama mazhab wujudiyah adalah dok-trin Wahdat al wujud. Pengkajian al Fansuri atas doktrin ini adalah tak lebih dari sebuah reproduksi dan pen-jelasan Melayu atau ajaran-ajaran ibnu 'Arabi secara mengagumkan dan kemudian dielaborasi lebih jauh oleh Syamsuddin Sumatrani yang karya dan ajaran-ajarannya pertama kali diperkenalkan ke dunia luar oleh sejumlah ilmuwan Belanda, tak pelak adalah eksponen terbesar aliran wuju-diah setelah al Fansuri.( Sayyed Hossen Nasr, 2003, 372).

Pengajaran Syamsuddin Sumatrani tentang Tuhan dengan co-rak paham Wahdat al wujud dapat dikenal dari pembicaraannya tentang maksud kalimat tauhid ( لا اله الا الله ) yang secara harfiah berarti tidak ada Tuhan selain Allah. Ia menjelaskan bahwa kalimat tauhid tersebut bagi salik (penempuh jalan tasawuf) tingkat pemula (almuhtadi) dipahami dengan pengertian bahwa tidak ada ma'bud (yang berarti disembah) kecuali Allah; bagi yang berada pada tingkat menengah (al muthawasith) kalimat itu dipahami dengan pengertian bahwa tiada maqshud (yang dikehendaki) kecuali Allah SWT dan bagi siapa yang sudah be-rada pada tingkat penghabisan (al muntahi) kalimat itu dipahami dengan pengertian bahwa tidak maujud (wujud) kecuali Allah SWT( Abdul Karim Al Jilli, tt, 27) dan pema-haman yang ketiga, atau tingkat al muntahi yang dilakukan oleh ka-langan sufi penganut paham wahdat al wujud, paham inilah yang mem-bedakannya dengan kalangan sufi lainnya.

Seperti Ibnu 'Arabi Syamsud-din Sumatrani dalam pengajarannya juga mengajak pengikutnya agar mentasybihkan dan sekaligus mentan-zihkan Tuhan. Ini suatu pengajaran penting yang perlu mendapatkan perhatian dari siapapun yang mau melakukan penilaian teolo-gis terhadap pengajarannya (Ab-dul Aziz, 1999, 46) yang sangat terkait dengan sepotong ayat yaitu "tiada satupun yang ( ليس كمسله شيء ) " ل menyerupainya".

Pengajaran Syamsuddin Sumatrani tentang Tuhan dengan co-rak paham wahdat al wujud dikenal juga dengan pengajaran tentang "mar-tabat tujuh" yakni tentang satu wujud dengan tujuh martabatnya. Pengajarannya tentang ini persis seper-ti yang diajarkan Muhammad bin Fadhlillah Al-Burhanpuri (w.1030 H / $1620 \mathrm{M}$ ) yang diduga kuat sebagai orang pertama yang mem-bagi martabat wujud itu kepada tujuh kategori, ketujuh martabat wujud itu adalah : martabat alhadiyah, martabat wahdah, marta-bat wahidiyah, martabat 'alam arwah, martabat 'alam mitsal, marta-bat 'alam ajsam (tubuh-tubuh ma-teri), dan martabat 'alam insan (manusia). Al-Burhanpuri pernah mengingatkan bahwa sebutan marta-bat ketuhanan tidak boleh digunakan atau dipakai untuk martabat alam / makhluk dan begitu pula sebaliknya. Akan tetapi ia tidak 
menunjukkan martabat-martabat yang mana saja yang termasuk kedalam kategori mar-tabat ketuhanan itu, dan mana pula yang termasuk kategori dalam kategori martabat alam / makhluk. Pada pengajaran Syamsuddin Sumatrani keterangan secara ekspl-isit tentang dua kategori dasar itu (martabat ketuhanan dan martabat 'alam / makhluk) tidak dijumpai. Ken-dati demikian, kesimpulan ten-tang itu bisa ditetapkan. Tiga marta-bat pertama disebut anniyat Allah, maksudnya martabat wujud aktual Tuhan, sedang empat martabat berikutnya disebut martabat anniyyat almakhluq atau martabat wujud ak-tual makhluk.( Abdul Aziz, 1999, 49-50).

Ketujuh martabat dimaksud dijelaskan sebagai berikut:

\section{Martabat Pertama}

Martabat wujud pertama masyhur dengan sebutan martabat ahadiyah (keesaan / keunikan) yakni wujud objektif, dan wujud aktual Tu-han bukan ide, konsep atau wujud 'ilmi tentang Tuhan. Wujud objektif Tuhan itu adalah zat-Nya sendiri yang merupakan dasar bagi muncul-nya manifestasi, tajalli atau penampa-kan diri-Nya. Itulah sebab-nya dikatakan dalam pengajarannya bahwa wujud pada martabat pertama itu suci dari segala macam sifat, nama atau batasan lainnya. Sebab sifat, nama dan batasan lainnya itu adalah manifestasi, tajalli atau penam-pakan dari wujud tersebut bukan wujud itu sendiri. Wujud atau zat Tuhan itu amat suci dari segala batasan. Ini berarti bahwa wujud atau zatNya itu antara lain tidak dibatasi oleh tempat atau ruang yang terbatas. Kendati ia boleh saja dikatakan be-rada di 'arasy, di langit, di bumi dan sebagainya, karena ia amat suci dari segala macam batasan, juga suci dari batasan tempat atau ruang tersebut. Kendati ia memanifestasikan si-fat-sifat atau namanama, karena amat suci dari segala batasan juga suci dari keterbatasan pengertian yang dikandung oleh setiap sifat dan nama-nama itu. Ia tidak terbatas, misalnya oleh batasan nama Al-'Alim (yang maha mengetahui), bahkan tidak terbatas oleh nama AlMuthlaq (yang tak terbatas) dan merupakan zat semata mata.(Abdul Aziz, 1999, 51-52).

\section{Martabat Kedua}

Martabat kedua disebut marta-bat wahdah (keesaan / kesatuan), yaitu penampakan (tajli, ta'ayun) dari Tuhan tahap pertama, dan kedua ini tidak mengacu kepada wujud aktual atau zat Tuhan, tetapi kepada sesuatu yang menampakan diri di dalam diri atau zatNya, yaitu wujud-wujud 'ilmi yang bersifat 'ijmali (global), kecantikanNya yang bersifat 'ijmali (global) dalam kan-dungan sifat-sifat dan nama-namaNya, atau wujudNya yang mutlak dengan segala keadaan-keadaan ketuhanan dan kemakhlukan yang bersifat global da-lam ilmuNya yang bersifat mutlak (umum). Dengan kata lain, manifes-tasi yang muncul dalam diri Tuhan atau ilmuNya baru bersifat global, ijmali atau umum. Ide-ide atau keadaan-keadaan yang terdapat da-lam ilmu Tuhan yang bersifat ijmali itu, biasa juga diibaratkan oleh kalangan penganut paham martabat tujuh seperti huruf-huruf yang banyak yang masih bersatu dalam tinta yang terdapat di mata pena. Jadi perbeda-an dalam satu ide dengan ide yang lain, atau satu keadaan dengan keadaan yang lain belum muncul( Abdul Aziz, 1999, 53-54) dan Syamsuddin Sumatrani menyebut untuk wujud aktual ciptaan pertama oleh Tuhan dengan Nur Muhammad.

\section{Martabat Ketiga}

Martabat ketiga dikenal dengan sebutan wahidiyyah (kesatuan). Martabat ketiga ini masih merupakan penampakkan 
atau tajalli di dalam diri Tuhan. Bila pada marta-bat kedua merupakan hasil tajalli wujud Tuhan dengan satu nama yaitu nama Allah SWT, maka pada martabat ketiga merupakan hasil tajalli wujud Tuhan dengan dua nama, yaitu nama Al-Rahman Al-Rahim. Tajalli wujud Tuhan dengan nama Al Rahman menghasilkan munculnya penge-tahuan yang terperinci dalam diri Tu-han tentang sifat-sifat dan nama-namaNya sendiri, sedang tajalli wujudNya dengan nama Al-Rahim menghasilkankemunculan pengetahuanNya yang terperinci ten-tang hakikat-hakikat 'alam (a'yan tsa bitah). Penampakan tahap kedua yang menjadi martabat ketiga ini, merupakan bentuk (gambar) dan hamba bagi kedua nama Tuhan itu, sedang kedua nama tersebut menjadi Tuhan bagi penampakan tahap kedua itu. Dalam pengajaran Syamsuddin Sumatrani juga ditegaskan bahwa a'yan tsabitah tidaklah memiliki wujud aktual, bahkan a'yan tsabitah tidak mencium aroma hidup.( Abdul Aziz, 1999, 55).

Martabat pertama, kedua dan ketiga yang telah dikemukakan yaitu; Ahadiyah, Wahdah dan Wahidiyah, merupakan 'aniyyah Tuhan, karena menurut pengajaran Syamsuddin Su-matrani, seperti halnya juga pengaja-ran Al Burhanpuri, adalah sama-sama qadim (dahulu tanpa per-mulaan atau tanpa didahului oleh tia-da). Ini berarti bahwa ketiga marta-bat itu dari segi waktu, keberadaan martabat kedua tidak lebih kemudian dari keberadaan pertama, dan tidak pula martabat ketiga lebih kemudian dari martabat kedua. Ini berarti uru-tan pertama, kedua dan ketiga tidak mengacu kepada waktu (zaman), tapi mengacu kepada penetapan akal ten-tang aspek mana yang menjadi alasan bagi aspek yang lain.

4. Martabat Keempat

Martabat keempat menurut Syamsuddin Sumatrani disebut alam arwah. Yaitu merupakan tajalli Tu-han tahap ketiga. Menurutnya tajalli Tuhan tahap ketiga ini, tidak lagi ber-langsung dalam dirinya, tetapi bukan pada diriNya (fighairih). Ini berarti ia haruslah menciptakan alam. Penciptaan alam ini oleh Tuhan ber-awal dengan penciptaan makhluk pertama. Makhluk pertama itu adalah nur (cahaya), yang dalam pengajaran-nya juga disebut dengan sejumlah nama, diantaranya Ruh $\mathrm{Mu}-$ hammad, Nur Muhammad, akal dan Alqalam a'la (pena tertinggi) penamaan makhluk pertama itu dengan nama Ruh Muhammad, Nur Muhammad beserta nama lainnya diperkuat dan didasarkan kepada sejumlah ungkapan yang dipahaminya sebagai sabda nabi Muhammad.( Abdul Aziz, 1999, 86). Dan menurutnya lagi, bahwa Ruh atau Nur Muhammad bersama dengan segala arwah yang diciptakan Tuhan, termasuk kedalam kategori alam arwah. Alam arwah itu tampaknya meliputi para malaikat, jin, setan, iblis, ruh manusia, ruh binatang dan ruh tumbuh-tumbuhan. Pembicaraan-nya tentang ruh lebih banyak mengaju kepada ruh manusia, karena arwah manusia adalah martabat tertinggi di kalangan arwah. Arwah itu dilukiskan dalam pengajarannya sebagai makhluk seperti (mirip sifat-nya) dengan sifat-sifat Tuhan, tidak makan dan tidak minum, mujarrad (sunyi dari materi dan bentuknya), tidak dilihat oleh mata kepala, tidak dapat dijangkau oleh indra lahir dan tinggi martabat mereka. Mereka meru-pakan baying-bayang (zhilalat) a'yan tsabitah.( Abdul Aziz, 1999, 90,93).

\section{Martabat Kelima}

Martabat wujud yang kelima adalah alam mitsal, yaitu alam segala rupa, alam segala contoh atau alam segala bentuk. Alam mitsal itu diru-muskannya sebagai suatu yang mu-rakkab (tersusun), lathif (halus), ghayr mutajazzi (tidak mengandung bagian), la muba'ad (tidak dapat dibagi), la mukhraq (tidak bisa dipisah-pisah), la multa'im (tidak bisa 
bersatu dengan yang lain) dan masih termasuk alam ghaib yakni tidak dapat ditangkap oleh panca inde-ra lahir. Dari rumusan tersebut dapat dipahami dengan pengertian bahwa alam mitsal tersusun menjadi jasad-jasad yang beraneka bentuk tapi masih bersifat halus (imateri), dan jasad-jasad imateri tersebut tidak dapat dirusak, dicerai beraikan atau disatukan antara yang satu dengan yang lainnya. Dalam pengajarannya Syamsuddin Sumatrani dikatakan bahwa nur (cahaya) yang diciptakan Tuhan merupakan selubung pertama bagi diri-Nya dalam alam arwah dan alam mitsal.( Abdul Aziz, 1999, 94, 95).

\section{Martabat Keenam}

Martabat wujud yang keenam adalah alam ajsam, yaitu alam yang dapat ditangkap oleh panca indera lahir manusia. Dalam pengajaran Syamsuddin Sumatrani disebut dengan sejumlah nama, diantaranya, alam ajsam (tubuh-tubuh materi), alam syahadah (kesaksian / yang disak-sikan) dan alam mulk atau alam empiris. Alam ajsam telah diberikan batasan-batasan seperti tubuh yang tebal, tersusun, bisa dibagi-bagi, bisa dipadukan dan bisa ditangkap indera lahir, sebenarnya belum ditunjukkan apa saja yang termasuk dalam kate-gori alam empiris itu. Penegasan itu tidak di jumpai di dalam pengajaran Syamsuddin Sumatrani. Yang dapat dijumpai adalah pengajarannya tentang maksud-maksud penciptaan 'arasy, kursi, surge, neraka, langit dan bumi. Bila ia sependapat dengan Ibnu 'Arabi dan pengikutnya yang memahami surga dan neraka sebagai alam barzakh (mitsal) maka jadilah alam empiris itu meliputi 'arasy, kursi, tujuh lapis langit dan bumi dan ini sesuai dengan pemahaman para ulama yang memasukkan 'arasy dan kursi kedalam kategori alam empiris.
7. Martabat Ketujuh

Martabat wujud yang ke tujuh adalah alam insan (manusia). Menurut Syamsuddin Sumatrani, pem-bicaraan tentang manusia merupa-kan bagian paling penting dalam pengajarannya tentang alam. Ini disebabkan karena dalam tasawuf-nya, sebagaimana tasawuf Ibnu 'Arabi dan para pengikutnya, ma'rifah Allah (mengenal Allah) me-lalui hati atau batin, sebagai tujuan tertinggi dalam tasawufnya, tidak mungkin dicapai atau diperoleh seseorang yang meyakini kehidupan tasawuf, bila ia tidak berhasil mengenal dirinya sendiri. Dalam pengajaran Syamsuddin Sumatrani, begitu juga Ibnu Arabi, ungkapan (siapa yang mengenal dirinya, niscaya ia mengenal Tuhannya) ber-ulangkali dapat dijumpai dan tampak diyakini sebagai hadis Nabi Muhammad SAW. Pengenalan terha-dap diri sendiri itu maksudnya terutama mengenai aspek ruh (jiwa atau nyawanya). Menurut Syamsuddin Sumatrani, penciptaan manusia merupakan realisasi dari kehendak Tuhan untuk bertajalli pada bukan diri-Nya dengan tajalli yang paling jelas. Alam manusia disebut juga syay'ja mi'; yakni suatu yang menghimpun semua martabat tajalli, wahdah, wahidiyah, ruh dan tubuh yang gelap. Nama Tuhan yang berta-jalli melalui alam manusia itu adalah nama $\mathrm{Al}$ Jami' (yang maha menghim-pun).

$$
\text { Manusia menurut pelajaran }
$$

Syamsuddin Sumatrani bila dilihat dari unsur-unsur lahiriah yang empat yakni; tanah, air, udara dan api dise-but al insan al basyariyyah (manusia lahir / kulit) sedangkan bila dilihat dari unsur-unsur bathiniyyahnya, al insan al haqiqi (manusia sejati / haqiqi). Unsur-unsur bathiniyyah itu menurutnya adalah wujud, 'ilm, nur dan syuhud, sedangkan yang dimak-sudkannya dengan wujud itu adalah zat, dan dengan 'ilm adalah si-fat-sifat, dengan nur adalah 
nama-nama, dan dengan syuhud ada-lah perbuatan-perbuatan.

Martabat wujud dari yang keem-pat sampai yang ke tujuh (alam arwah, alam mitsal, alam ajsam alam dan alam insan) merupakan anniyah makhluk, karena bersifat wujud ak-tual makhluk dan disebut muhdats (yang dijadikan / diciptakan), disamping itu keempat martabat terse-but menggunakan awal kata "alam" yang berawal, yang berarti bukan anniyyah Allah yang qa dim.

\section{SIMPULAN}

Syamsuddin Sumatrani mempu-nyai latar belakang kehidupan yang susah dilacak dengan pasti, kare-na minimnya informasi mengenai dirinya di saat-saat ia be-lum mengemuka, sehingga tidak diketahui di mana tempat ia lahir, tanggal, hari, bulan bahkan tahunnya tidak dijumpai informasi tentang itu.

\section{DAFTAR RUJUKAN}

Abdullah, Hawash, Perkembangan Ilmu Tasawuf dan Tokoh-tokohnya di Nusanta-ra, Surabaya, Al Ikhlas, 1980.

Abdul Hadi, WM, Hamzah Fansuri Risalah dan Puisi-puisinya, Bandung, PN Mi-zan, cet I, 1995.

Al Jili, Abdul Karim, Al Ihsan Al Kamil fi Ma'rifat Al Awril wa Al Awakhir, Beirut, Dar al Fikr, tt.

Dahlan, Abdul Aziz, Prof, DR, Penilaian Teologis Atas Paham Wahdat Al Wujud, Tuhan, Alam, Manusia, Dalam Tasawuf Syamsuddin Sumatrani, Padang, IAIN Press, 1999.

Nasr, Sayyed Hussein (Ed), Ensiklopedi Tematis Spritualitas Islam, Terjemahan oleh Tim Penterjemah Mizan, Bandung, PN Mizan, cet I, 2003.
Syamsuddin mulai dikenal ketika Sultan Syah Alam yakni Sul-tan Alauddin Riayat Al Mukamil (ayah dari sultan Iskandar Muda) men-jadi penguasa, diduga ia telah menjadi Saikh al Islam (1589-1604) dan dilanjutkan ketika Sultan Iskan-dar Muda menjadi penguasa (1604-1636), sayang ia telah wafat 6 tahun sebelum Sultan Iskandar Muda wafat yakni tahun 1630. Ia sa-lah seorang murid Syekh Hamzah Fansuri yang sama-sama bermahzab wujudiyyah berpaham wahdat al wujud dalam tasawufnya. Pelajaran-nya tentang Tuhan dengan corak wahdat al wujud telah dikemasnya sedemikian rupa melalui satu wujud dalam tujuh martabat yang dikenal dengan martabat tujuh. Hal inilah yang membuatnya dikenal sampai sekarang terutama bagi yang ingin mengetahui martabat tujuh sebagai pengajaran spesialis dari Syamsuddin Sumatrani.

Samad, Duski, Drs, M.Ag, Sufi Nusantara dan Pemikirannya, Jakarta, PN Minangkabau Foundation, cet I, 2000.

Tim Penulis IAIN Sumatera Utara, Pengantar Ilmu Tasawuf, Medan, Proyek PPTA / IAIN Sumatera Utara, 1981 / 1982.

Tim Penulis IAIN Syarif Hidayatullah, Ensiklopedi Islam Indonesia, Jakarta, PN Djambatan, 1992. 